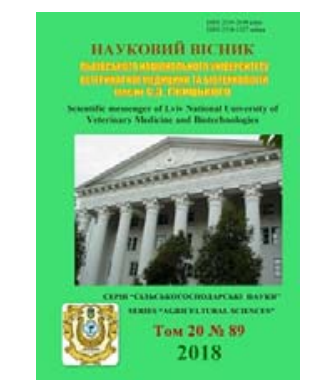

UDC 631.86:633.15

Науковий вісник Дьвівського національного університету ветеринарної медицини та біотехнологій імені С.3. Гжицького

\author{
Scientific Messenger of Lviv National University \\ of Veterinary Medicine and Biotechnologies
}

\title{
Formation and productivity of photosynthetic apparatus of maize plants for the action of Polimiksobakteryn - a plant growth stimulator
}

\author{
L.A. Shevchenko, L.M. Tokmakova \\ Institute of Agricultural Microbiology and of Agroindustrial Manufacture, NAAS, Chernihiv, Ukraine
}

Article info

Received 03.09.2018 Received in revised form 04.10.2018 Accepted 05.10.2018

Institute of Agricultural Microbiology and of Agroindustrial Manufacture, NAAS, Shevchenko Str. 97 , Chernihiv, 14027, Ukraine. Tel. $+38-063-529-69-84$ E-mail: shevchenkolyubov@ukr.net

\begin{abstract}
Shevchenko, L.A., \& Tokmakova, L.M. (2018). Formation and productivity of photosynthetic apparatus of maize plants for the action of Polimiksobakteryn - a plant growth stimulator. Scientific Messenger of Lviv National University of Veterinary Medicine and Biotechnologies, 20(89), 47-51. doi: $10.32718 /$ nvlvet8908
\end{abstract}

Currently, the introduction of new techniques for corn growing technology, which involves the use of microbial drugs - growth stimulators and the study of their effects on the process of photosynthesis is relevant. In the conditions of field experiment on black soil, the effect of microbial preparation Polimiksobakteryn - a growth stimulator of plants on various methods of its application on the formation and productivity of the photosynthetic apparatus of maize plants of hybrid Dniprovsky 181 SV was studied. It was determined that the bacterialisation of seeds with subsequent surface treatment of vegetable corn plants with Polymiksobacteryn in the phase of 3-5 or 7-9 leaves - agroprimus, which provides activation of the process of photosynthesis. In particular, for the combination of bacteritisation and surface treatment of vegetative plants, the area of the leaf surface increases to $5315 \mathrm{~cm}^{2} /$ plant in the flowering phase, which is $40.0 \%$ more relative to the control variant, this indicates an improvement in the conditions of growth and development of maize due to the growth-stimulating properties of the microbial preparation. The index of chlorophyll content $(a+b)$ increases, and among all the experimental variants, the highest value of $146.7 \mathrm{mg} / 100 \mathrm{~g}$ of leaves installed with the combined use of Polimyksobacteryn - the bacteritisation of seeds and surface treatment by vegetation, which is $36.2 \%$ higher than the benchmark $107.7 \mathrm{mg} / 100 \mathrm{~g}$ of leaves. The increase in area of the leaf surface was accompanied by raising in the net photosynthesis efficiency of $6.34 \mathrm{~g} / \mathrm{m}^{2} \mathrm{per}$ day in the control version to $10.39 \mathrm{~g} / \mathrm{m}^{2}$ per day (or 63.8\%) as a result of bacteritisation and surface treatment of corn vegetable plants, indicating about formation of the optimum structure and productivity of the paper machine. It should be noted that according to the data, the method of using microbial preparation, which included seeding bacteria and superficial treatment of vegetative plants, better than taking bacteria or seed treatment separately. Therefore, in the cultivation of maize, the use of the microbial preparation Polymiksobacteryn, the growth stimulator of plants, by bacterialization of seeds in combination with surface treatment of plants in vegetation, increases the quantitative and improves qualitative parameters of photosynthetic activity of plants, which is essentially of practical importance for increasing the productivity of this culture.

Key words: corn, Polimiksobakteryn, area of sheet surface, photosynthetic pigments, pure productivity of photosynthesis.

\section{Формування і продуктивність фотосинтетичного апарату рослин кукуру- дзи за дії Поліміксобактерину - стимулятора росту рослин}

\author{
Л.А. Шевченко, Л.М. Токмакова
}

Інститут сільськогосподарської мікробіологї̈ та агропромислового виробництва НААН, м. Чернігів, Україна

\footnotetext{
На даний час впровадження нових прийомів технології вирощування кукурудзи, яка включає застосування мікробних препаратів - стимуляторів росту рослин та дослідження їх впливу на процес фотосинтезу є актуальним. В умовах польового досліду на чорноземі вилуженому вивчено дію мікробного препарату Поліміксобактерину - стимулятора росту рослин за різних прийомів його застосування на формування і продуктивність фотосинтетичного апарату рослин кукурудзи гібриду Дніпровський 181 СВ. Встановлено, шо бактеризачія насіння з подальшою поверхневою обробкою вегетуючих рослин кукурудзи Поліміксобактерином у фазі 3-5 або 7-9 листків - агроприйом, який забезпечує активізачію процесу фотосинтезу. Зокрема, за поєднання бактеризації $i$
} 
поверхневої обробки вегетуючих рослин простежується збільшення площчі листкової поверхні до 5315 см²/рослину у фазі иввітіння, щзо на 40,0\% більше відносно контрольного варіанту, це свідчить про покрашення умов росту і розвитку кукурудзи за рахунок рістстимулючих властивостей мікробного препарату. Зростає показник вмісту суми хлорофілів (a + b), $i$ серед усіх варіантів досліду найвище значення - 146,7 мг/100 г листя встановлено при поєднаному застосуванні Поліміксобактерину - бактеризації насіння та поверхневої обробки по вегетації, шо на 36,2\% перевищувало контрольний показник 107,7 мг/100 г листя. 3більиення площі листової поверхні супроводжувалось підвищенням показника чистої продуктивності фотосинтезу від 6,34 г/м ${ }^{2}$ за добу в

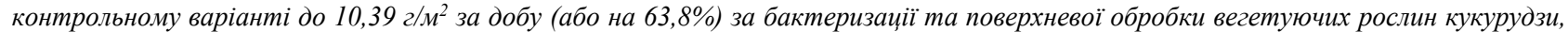
що свідчтть про формування оптимального за структурою та продуктивністю листкового апарату. Варто зазначити, щьо за даними показниками спосіб застосування мікробного препарату, який включав $і$ бактеризацію насіння $і$ поверхневу обробку вегетуючих рослин, є кращчм, ніж прийом бактеризачії насіння або поверхневої обробки окремо. Тому, при вирощуванні кукурудзи застосування мікробного препарату Поліміксобактерину - стимулятора росту рослин, иляхом бактеризації насіння у поєднанні з поверхневою обробкою рослин по вегетацї, підвищує кількісні та покрашує якісні параметри фотосинтетичної активності рослин, щзо має принципово важливе практичне значення для підвищення продуктивності даної культури.

Ключові слова: кукурудза, Поліміксобактерин, площуа листкової поверхні, фотосинтетичні пігменти, чиста продуктивність фотосинтезу.

\section{Вступ}

Кукурудза (Zea mays L.) є однією з найпоширеніших та найцінніших культур світового землеробства. Особливість цієї культури визначається специфічним, ефективнішим типом фотосинтезу $\mathrm{C}_{4}$ (Yanosh, 2012). Тому важливе значення має розробка і впровадження таких технологій вирощування кукурудзи, які б забезпечували тривале та ефективне використання сонячної енергії посівами цієї культури і сприяли більшому нагромадженню органічної речовини.

Відомо, що в основі росту і розвитку рослинного організму $\epsilon$ процес фотосинтезу, який забезпечує формування продуктивності культури. Вирішальними факторами продуктивності фотосинтезу є розмір площі та тривалість активної діяльності листкової поверхні рослин (Rubin, 1969; Nichiporovich, 1972). Фотосинтетичні пігменти є найважливішими компонентами фотосинтетичного апарату листків та чутливими індикатором інтенсивності процесу фотосинтезу, їх вміст $є$ фізіологічним показником для характеристики дії чинників на рослини (Weis, 1991; Saglam et al., 2011). У науковій літературі (Mamchur, 2013) також повідомляється, що на вміст хлорофілів значною мірою можуть впливати регулятори росту рослин, які залежно від основного діючого компонента та норм і способів застосування, сприяють підвищенню його вмісту у листках сільськогосподарських культур. Також одним із показників, який характеризує активність фотосинтетичного апарату рослин - чиста продуктивність фотосинтезу, яка визначає суху масу врожаю, що створюється $1 \mathrm{~m}^{2}$ листкової поверхні посіву за добу.

Одним із елементів нової технології у землеробстві є використання мікробних препаратів - стимуляторів росту рослин (Volkogon, 2015) та вивчення їх дії на формування i продуктивність фотосинтетичного апарату рослин кукурудзи є на сьогодні досить актуальним напрямом досліджень в аграрному виробництві. У зв'язку з вищевикладеним мета наших досліджень полягала у розробці прийомів застосування Поліміксобактерину - стимулятора росту рослин при вирощуванні кукурудзи та вивченні особливостей формування фотосинтетичного апарату рослин.

\section{Матеріал і методи досліджень}

Дослідження проводили в умовах польового досліду на вилуженому чорноземі дослідного поля Інституту сільськогосподарської мікробіології та агропромислового виробництва НААН України. Об'єктом дослідження була кукурудза гібриду Дніпровський 181 СВ. Агрохімічні показники грунту: вміст гумусу становить 2,12\%, легкогідролізованого азоту 95,2 мг/кг, рухомого фосфору - 226 мг/кг, обмінного калію -108 мг/кг, $\mathrm{pH}_{\text {сол. }}=5,30$.

Схема польового досліду включає: 1. Контроль без бактеризації та поверхневої обробки (ПО); 2. Бактеризація насіння; 3. Поверхнева обробка вегетуючих рослин у фазі 3-5 листків; 4. Бактеризація + поверхнева обробка вегетуючих рослин у фазі 3-5 листків; 5. Поверхнева обробка вегетуючих рослин у фазі 79 листків; 6. Бактеризація + поверхнева обробка вегетуючих рослин у фазі 7-9 листків.

Повторність досліду триразова, площа однієї дослідної ділянки $=50,4 \mathrm{~m}^{2}$. Бактеризацію насіння кукурудзи проводили Поліміксобактерином згідно з СОУ 01.11-37-783 (SOU 01.11-37-783:2008). Поверхневу обробку вегетуючих рослин проводили механізовано. Робоча суміш містила: 200 л води та 0,5 л Поліміксобактерину з розрахунку на 1 га посівів. Площу листкового апарату рослин визначали методом висічок (Gricayenko et al., 2003). Визначення концентрації хлорофілів проводили впродовж вегетаційного періоду рослин кукурудзи. Листки відбирали із середнього ярусу рослини з максимально однаковою освітленістю. Загальний вміст хлорофілів $a$ і $b$ визначали фотометричним методом (Gricayenko et al., 2003). Чисту продуктивність фотосинтезу рослин кукурудзи розраховували за відповідною формулою, викладеною в підручнику (Gorodnij et al., 2005).

\section{Результати та їх обговорення}

Однією з основних морфологічних характеристик, за зміною якої можна судити про формування фотосинтетичного апарату $\epsilon$ площа листкової поверхні рослин. В умовах польового досліду у фазу трубкування рослин встановлено, що бактеризація насіння Поліміксобактерином сприяла збільшенню площі листкової поверхні до $4683 \mathrm{~cm}^{2} /$ рослину при контрольному показнику $-3714 \mathrm{~cm}^{2} /$ рослину та найкращі 
показники у варіанті з бактеризацією насіння та поверхневою обробкою вегетуючих рослин мікробним препаратом у фазі 3-5 листків становила $5015 \mathrm{~cm}^{2} /$ рослину (рис. 1). У фазу цвітіння бактеризація + поверхнева обробка вегетуючих рослин у фазі 3-5 листків забезпечувала збільшенню площі листкової поверхні до $5315 \mathrm{~cm}^{2} /$ рослину, що на 40,0\% більше відносно контрольного варіанту, що свідчить про ефективне використання протягом вегетації фотосинтетично-активної радіації рослинами у всіх агроприйомах. У фазу молочно-воскової стиглості площа асиміляційної поверхні зменшується за всіма варіантами досліду, що пов'язано з процесом старіння і відмирання листя нижнього ярусу, які повністю віддають накопичені пластичні речовини репродуктивній частині урожаю. Так, у контрольному варіанті площа асиміляційної поверхні становила $3660 \mathrm{~cm}^{2} /$ рослину, 3 бактеризацією насіння та подальшою поверхневою обробкою вегетуючих рослин Поліміксобактерином у фазі 3-5 листків - $5122 \mathrm{~cm}^{2} /$ рослину. Це свідчить про подовження періоду функціонування фотосинтетичного апарату рослин кукурудзи, що дає можливість накопичити більше органічної речовини, необхідної для формування майбутнього урожаю.

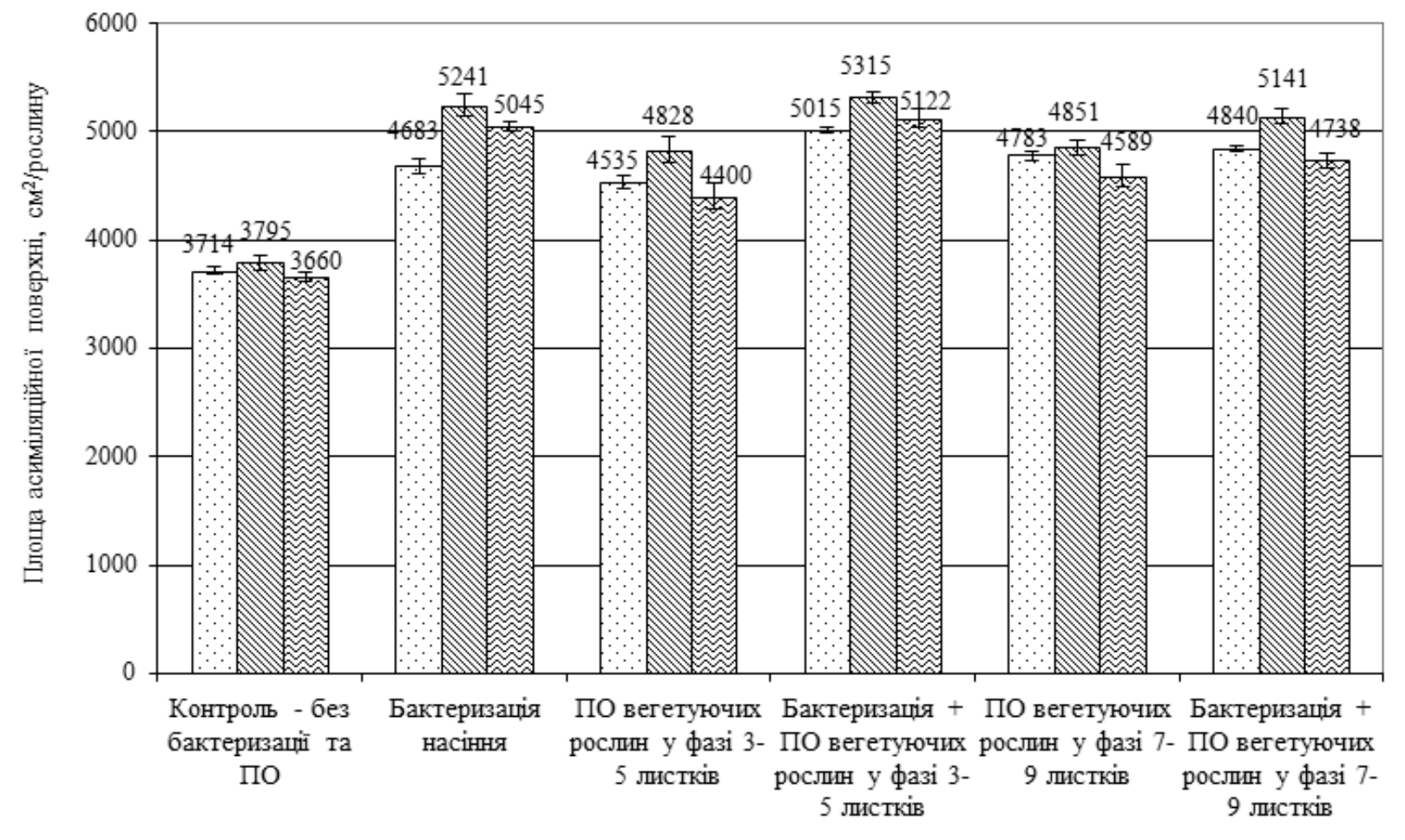

$\square$ фаза виходу у трубку $\mathbb{\$}$ фаза цвітіння $\mathbf{9}$ фаза молочно-воскової стиглості

Рис. 1. Динаміка формування площі листової поверхні рослин кукурудзи за дії Поліміксобактерину

Важливе значення для встановлення впливу Поліміксобактерину на фотосинтетичну активність рослин кукурудзи має визначення динаміки вмісту фотосинтетичних пігментів - головних фоторецепторів рослинних клітин. У фазу виходу в трубку у варіанті 3 бактеризацією насіння та поверхневою обробкою вегетуючих рослин у фазі 3-5 листків вміст хлорофілу $a$, який є фотосинтетично активним пігментом, становив 120,1 мг/100 г листя, при контрольному показнику $-88,2$ мг/100 г листя (табл. 1).

Найінтенсивніше процес біосинтезу пігментів у рослин кукурудзи відбувався у фазі цвітіння. Серед усіх варіантів досліду найвищий вміст суми хлорофілів $(a+b)$ встановлений при бактеризації насіння та поверхневій обробці вегетуючих рослин у фазі 35 листків - 146,7 мг/100 г листя, що на 39,0 мг/100 г листя перевищувало контроль (107,7 мг/100 г листя).
В інших варіантах досліду вміст суми хлорофілів $a+b$ також перевищував значення контролю, однак меншою мірою, ніж у зазначеному вище варіанті.

У фазу молочно-воскової стиглості у варіанті бактеризація + поверхнева обробка вегетуючих рослин Поліміксобактерином у фазі 3-5 листків вміст хлорофілу знижується від 146,7 мг/100 г листя до 92,0 мг/100 г листя, завдяки цьому рослинам кукурудзи, при вирощуванні яких застосовували Поліміксобактерин характерне уповільнене старіння і вони зберігають зелений колір листків довше, ніж рослини контрольного варіанту, що має велике значення, оскільки $з$ літературних джерел (Andrianova, 2000) відомо, що вміст основних пігментів фотосинтезу визначає фізіологічний стан рослин, їх здатність до формування врожаю, а також впливає на їх стійкість до несприятливих умов. 
Таблиця 1

Вплив Поліміксобактерину на вміст фотосинтетичних пігментів у листках рослин кукурудзи

\begin{tabular}{|c|c|c|c|}
\hline \multirow{2}{*}{ Варіанти досліду } & \multicolumn{3}{|c|}{ Вміст пігментів, мг/100 г листя } \\
\hline & хлорофіл $a$ & хлорофіл $b$ & хлорофіл $a+b$ \\
\hline \multicolumn{4}{|c|}{ Фаза виходу у трубку } \\
\hline Контроль - без бактеризації та ПО & $70,5 \pm 0,4$ & $14,8 \pm 0,7$ & $85,3 \pm 1,1$ \\
\hline Бактеризація насіння & $77,8 \pm 1,1$ & $15,7 \pm 0,4$ & $93,5 \pm 1,4$ \\
\hline ПО вегетуючих рослин у фазі 3-5 листків & $83,1 \pm 0,8$ & $15,3 \pm 1,0$ & $98,4 \pm 0,6$ \\
\hline Бактеризація + ПО вегетуючих рослин у фазі 3-5 листків & $86,2 \pm 0,9$ & $15,6 \pm 1,1$ & $101,8 \pm 1,1$ \\
\hline ПО вегетуючих рослин у фазі 7-9 листків & $91,0 \pm 1,3$ & $17,2 \pm 1,2$ & $108,2 \pm 0,5$ \\
\hline Бактеризація + ПО вегетуючих рослин у фазі 7-9 листків & $94,7 \pm 1,1$ & $17,5 \pm 0,9$ & $112,2 \pm 1,9$ \\
\hline \multicolumn{4}{|c|}{ Фаза извітіння } \\
\hline Контроль - без бактеризації та ПО & $88,2 \pm 0,9$ & $19,5 \pm 1,5$ & $107,7 \pm 1,0$ \\
\hline Бактеризація насіння & $111,1 \pm 1,2$ & $23,0 \pm 0,8$ & $134,1 \pm 0,5$ \\
\hline ПО вегетуючих рослин у фазі 3-5 листків & $100,2 \pm 0,6$ & $22,2 \pm 0,8$ & $122,4 \pm 0,9$ \\
\hline Бактеризація + ПО вегетуючих рослин у фазі 3-5 листків & $120,1 \pm 1,4$ & $26,6 \pm 1,9$ & $146,7 \pm 1,4$ \\
\hline ПО вегетуючих рослин у фазі 7-9 листків & $101,9 \pm 0,2$ & $22,2 \pm 0,7$ & $124,1 \pm 0,7$ \\
\hline Бактеризація + ПО вегетуючих рослин у фазі 7-9 листків & $106,0 \pm 0,5$ & $21,1 \pm 1,3$ & $127,1 \pm 1,4$ \\
\hline \multicolumn{4}{|c|}{ Фаза молочно-воскової стиглості зерна } \\
\hline Контроль - без бактеризації та ПО & $58,8 \pm 0,5$ & $13,4 \pm 0,1$ & $72,2 \pm 0,5$ \\
\hline Бактеризація насіння & $64,9 \pm 0,7$ & $15,7 \pm 0,1$ & $80,6 \pm 0,8$ \\
\hline ПО вегетуючих рослин у фазі 3-5 листків & $64,4 \pm 0,2$ & $14,9 \pm 0,1$ & $79,3 \pm 0,2$ \\
\hline Бактеризація + ПО вегетуючих рослин у фазі 3-5 листків & $60,9 \pm 0,3$ & $13,7 \pm 0,1$ & $74,6 \pm 0,3$ \\
\hline ПО вегетуючих рослин у фазі 7-9 листків & $59,4 \pm 0,2$ & $14,1 \pm 0,1$ & $73,5 \pm 0,2$ \\
\hline Бактеризація + ПО вегетуючих рослин у фазі 7-9 листків & $74,0 \pm 0,4$ & $18,0 \pm 0,1$ & $92,0 \pm 0,5$ \\
\hline
\end{tabular}

Важливим показником оптимальної фотосинтетичної діяльності посівів сільськогосподарських культур є чиста продуктивність фотосинтезу, яка визначається кількістю пластичних речовин, що нагромаджує рослина на одиницю листкової поверхні впродовж певного періоду (Nichiporovich, 1972). У роботі H.M. Асанішвілі зі співавторами (Asanishvili et al., 2012) вказується на здатність рослин кукурудзи фор- мувати посіви з показниками чистої продуктивності фотосинтезу на рівні 16,0-16,9 г/м²×добу.

Досліджено, що чиста продуктивність фотосинтезу рослин у варіантах з різними прийомами застосування Поліміксобактерину при вирощуванні кукурудзи збі-

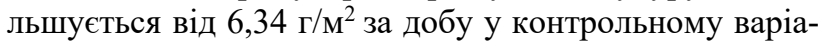

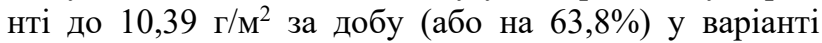
бактеризація + поверхнева обробка вегетуючих рослин у фазі 7-9 листків (табл. 2).

Таблиця 2

Чиста продуктивність фотосинтезу рослин кукурудзи за дії Поліміксобактерину

\begin{tabular}{|c|c|c|}
\hline \multirow{2}{*}{ Варіанти досліду } & \multicolumn{2}{|c|}{ Чиста продуктивність фотосинтезу } \\
\hline & $\Gamma / M^{2}$ за добу & до контролю, \% \\
\hline Контроль - без бактеризації та ПО & 6,34 & - \\
\hline Бактеризація насіння & 9,12 & 43,8 \\
\hline ПО вегетуючих рослин у фазі 3-5 листків & 6,78 & 6,9 \\
\hline Бактеризація + ПО вегетуючих рослин у фазі 3-5 листків & 9,04 & 42,5 \\
\hline ПО вегетуючих рослин у фазі 7-9 листків & 10,18 & 50,1 \\
\hline Бактеризація + ПО вегетуючих рослин у фазі 7-9 листків & 10,39 & 63,7 \\
\hline $\mathrm{HIP}_{05}$ & 0,56 & \\
\hline
\end{tabular}

Застосовуючи прийом бактеризації насіння та поверхневої обробки вегетуючих рослин у фазі 7-9 листків можливо підвищити чисту продуктивність фотосинтезу майже в 2 рази, до того ж фотосинтетичний апарат рослин кукурудзи даного варіанту функціонує довше протягом вегетаційного періоду.

\section{Висновки}

Результати наших досліджень дають підставу стверджувати, що застосування Поліміксобактерину стимулятора росту рослин при вирощуванні кукурудзи шляхом бактеризації насіння та подальшою поверхневою обробкою вегетуючих рослин у фазі 3-5 листків або 7-9 листків $є$ найбільш ефективнішим. Агроприйом забезпечує активізацію процесу фотосинтезу: збільшується площа листкової поверхні, вміст фотосинтетичних пігментів та чиста продуктивність фотосинтезу.

\section{References}

Andrianova, Ju. E. \& Tarchevskij I. A. (2000). Hlorofill i produktivnost' rastenij. M.: Nauka (in Russian).

Asanishvili, N.M., Serbenjuk G.A., \& Bondarchuk A.A. (2012). Fotosintetichna dijal'nist' i produktivnist' agrofitocenoziv kukurudzi zalezhno vid elementiv tehnologii viroshhuvannja u Pivnichnomu Lisostepu. 
Zbirnik naukovih prac' NNC 'Institut zemlerobstva NAAN", 75-81 (in Ukrainian).

Chikov, V.N. (2008). Jevoljucija predstavlenij o svjazi fotosinteza $\mathrm{i}$ produktivnosti rastenij. Fiziologija rastenij, 55(1), 140-154 (in Russian).

Gorodnij, M.M., Lisoval A.P., \& Bikin A.B., ta in. (2005). Agrohimichnyi analiz. K.: Aristei (in Ukrainian).

Gricayenko, Z.M., Gricayenko A.O., \& Karpenko V.P. (2003). Metody biologichnyh ta agrohimichnyh doslidzhen' roslyn i gruntiv. K.: ZAT "NICHLAVA" (in Ukrainian).

Mamchur, O.V. (2013). Fizioloho-biokhimichni osoblyvosti formuvannia produktyvnosti kukurudzy za vplyvu rehuliatoriv rostu roslyn. Naukovyi visnyk Lvivskoho natsionalnoho universytetu veterynarnoi medytsyny ta biotekhnolohii im. Gzhytskoho, 15, 1(2), 152-160. Rezhym dostupu: http://nbuv.gov.ua/UJRN/nvlnu_2013_15_1(2)_27 (in Ukrainian).

Mamchur, O.V. (2013). Rol fiziolohichno aktyvnykh rechovyn $\mathrm{v}$ ontohenezi roslyn kukurudzy. Naukovyi visnyk Lvivskoho natsionalnoho universytetu veterynarnoi medytsyny ta biotekhnolohii im. Gzhytskoho, 15, 3(3), 109-119. Rezhym dostupu: http://nbuv.gov.ua/UJRN/nvlnu_2013_15_3(3)_22 (in Ukrainian).
Yanosh, N. (2012). Kukurudza. Vinnytsia: FOP Korzun D.Iu. (in Ukrainian).

Nichiporovich, A.A. (1972). Teoreticheskie osnovy fotosinteticheskoj produktivnosti. Izd-vo AN SSSR (in Russian).

Rubin, B.A. (1969). Fiziologija sel'skohozjajstvennyh rastenij. Tom V (Fiziologija kukuruzy i risa). Izd-vo Moskovskogo un-ta (in Russian).

Saglam, A., Saruhan, N., Terzi, R., \& Kadroglu, A. (2011). The relations between antioxidant enzymes and chlorophyll fluorescence parameters in common bean cultivars differing in sensitivity to drought stress. Russian Journal of Plant Physiology, 58(1), 58-66. https://link.springer.com/article/10.1134/S102144371 101016X.

SOU 01.11-37-783:2008. (NASINNYA KUKURUDZY. Tehnologichnyi proces nanesennya mikrobnyh preparativ. Zagal'ni vimogy. Chynnyi vid 2009-0701). K.: Derzhspozhivstandart Ukraini, 2009 (in Ukrainian).

Volkogon, V.V. (2015). Mikrobni preparaty v suchasnyh agrarnyh tehnologiyah (naukovo-praktychni rekomendacii). Za red. V.V. Volkogona. Kyiv (in Ukrainian).

Weis, E. (1991). Chlorophyll fluorescence and photosynthesis: The basics. Annual Review of Plant Physiology and Plant Molecular Biology, 42, 313349. doi: 10.1146/annurev.pp.42.060191.001525. 